Reviews

Studia luridica Lublinensia vol. XXIX, 5, 2020

DOI: 10.17951/sil.2020.29.5.369-373

\title{
Wojciech Taras
}

Uniwersytet Marii Curie-Skłodowskiej w Lublinie, Polska

ORCID: 0000-0001-9643-8282

wojtar@umcs.pl

\section{Paweł Daniel, Filip Geburczyk, Akt informacji jako forma działania administracji publicznej, Warszawa 2019, ss. XXIV + 155}

Od połowy lat 80 . XX w. coraz większe zainteresowanie polskiej doktryny prawa publicznego budzi zasada jawności działań organów administracyjnych oraz wynikający z niej obowiązek informowania. Jedną z kilku przyczyn tego stanu rzeczy jest niekontrowersyjne stwierdzenie, że udzielanie informacji przez administrację stanowi specyficzną formę jej działania, a owa swoistość wyraża się przede wszystkim w trudności umieszczenia jej w ramach zastanych klasyfikacji. Nie powinna budzić zastrzeżeń konstatacja, że fundamentalnym powodem wszelkich sporów wokół informacji publicznej pozostaje nadal brak powszechnie akceptowanej definicji na gruncie nauk prawnych, mimo posługiwania się przez prawodawcę powyższym terminem ${ }^{1}$. Recenzowana książka to kolejny głos w dyskusji nad zagadnieniami społeczeństwa informacyjnego, nowymi nurtami zmieniającymi pojmowanie tradycyjnej roli administracji publicznej, sposobami definiowania pojęć prawnych oraz stanem polskiego prawodawstwa.

Monografia składa się ze wstępu, pięciu rozdziałów oraz podsumowania przeprowadzonych w pracy wywodów, ma więc klasyczny układ opracowań tego rodzaju. Warto od razu zwrócić uwagę na pewną kwestię. Otóż książka nie jest „przegadana", co do tej pory stanowiło cechę wielu rozpraw prawniczych, zwłaszcza ostatnich dziesięciu lat. Ich autorzy starali się wyjaśnić czytelnikom wszelkie aspekty prezentowanej problematyki, zapominając przy tym, że odbiorca jurydycznego traktatu posiada pewien zasób wiedzy na temat objęty jego tytułem, inaczej sięgnąłby po

1 Zob. W. Taras, Jawność działania administracji publicznej $w$ warunkach przeciażenia informacyjnego, [w:] Władza - obywatele - informacja. Ku nowemu porządkowi prawnemu. Ksiega pamiątkowa ku czci Profesor Teresy Górzyńskiej, red. I. Lipowicz, Warszawa 2014, s. 33-34. 
podręcznik. Tym razem autorzy nie popełnili tego błędu i skoncentrowali się bezpośrednio na istocie informacji publicznej oraz kontekstach jej funkcjonowania.

Pierwszy rozdział został zatytułowany Akt administracyjny w polskim systemie prawa-uwagi wprowadzające. Problem w tym, że w jego treści nie ma odniesień do powyższej formy działania administracji publicznej. Pozwolę sobie na sugestię, że mamy tu do czynienia z prostym błędem zastąpienia nazwy jednego aktu (administracyjnego, decyzji) nazwą innego (informacyjnego), stanowiącego rdzeń rozprawy, być może z powodu powszechności zwrotu ,akt administracyjny” albo z pośpiechu podczas redagowania książki lub też niestarannej korekty. Natomiast należy podkreślić prawidłowość wyjściowych założeń przyjętych przez autorów, a mianowicie zaznaczenie interdyscyplinarnego charakteru pojęcia informacji i w konsekwencji funkcjonowania w obiegu naukowym wielu jej definicji (s. 10), jak również wskazanie na dwa zasadnicze cele aktu informacji: informowanie społeczeństwa o działaniach podmiotów administracyjnych (cel informacyjny) oraz zapewnienie obywatelom czynnego udziału w wykonywaniu zadań należących do administracji (cel gwarancyjny). Ostatnia $\mathrm{z}$ tez ma wyjątkowe znaczenie dla problematyki badań nad jawnością i informowaniem, o czym dobitnie świadczy zwrócenie uwagi na gwarancyjny charakter informacji publicznej jeszcze w okresie Polski Ludowej $^{2}$. Trafnie połączono powyższy charakter z partycypacją społeczeństwa w sferach tworzenia prawa i jego stosowania, a także uznano powyższe zjawisko za przejaw odchodzenia od tradycyjnego modelu administracji publicznej, zbudowanego jedynie na fundamencie władczości, w kierunku współadministrowania i posługiwania się przez państwo metodami przekonywania i uzgadniania stanowisk za pomocą argumentacji, a nie nakazu. W dalszej części rozdziału autorzy wykazują, że działalność informacyjna nie jest zadaniem publicznym administracji (s. 23), lecz jej obowiązek informowania powstaje przy okazji realizacji nałożonych ustawą zadań, przez co ma charakter przekrojowy i powszechny.

Ramy rozdziału II zostały bardzo szeroko zakreślone, ponieważ pomieszczono $\mathrm{w}$ nim rozważania dotyczące proceduralizacji prawa administracyjnego $\mathrm{w}$ kontekście działań informacyjnych administracji publicznej. Autorzy omawiają więc przydatność odnowionych instrumentów typu kooperacja, zastanawiają się nad środkami zaradczymi wobec kryzysu współczesnej legislacji oraz konstatują, że materialne prawo administracyjne staje się nieskuteczne do sterowania nowoczesną administracją, a dopiero regulacje procesowe pozwalają na połączenie ustawowych gwarancji praw jednostek z postulatem elastyczności działań administracji publicznej (s. 33). Następnie zostały przybliżone dwa ujęcia proceduralizacji prawa w modelach normatywnym i deskryptywnym oraz klasyczna i postklasyczna teoria procesu, czyli materialny i procesowy model rozwiązywania sporów. Rozdział koń-

2 Zob. także: idem, Informowanie obywateli przez administrację, Wrocław-Warszawa-Kraków 1992, s. 29, 36. 
czy słuszna teza, iż procedury służą realizacji prawa materialnego, ale równocześnie modyfikują statykę opartego na nim porządku (s. 38). Ważne jest stwierdzenie, że pod wpływem proceduralizacji prawa powstają nowe formy działania administracji o cechach nietypowych, niemieszczące się w ich zastanej klasyfikacji (s. 50).

W rozdziale III została podjęta próba zdefiniowania aktu informacji w prawie administracyjnym jako narzędzia pozwalającego na współudział społeczeństwa w sprawowaniu władzy. Po przedstawieniu dotychczasowego dorobku doktryny w przedmiocie pojmowania, klasyfikacji i zmienności prawnych form działania administracji autorzy przywołali za M. Stahl szeroką definicję aktu informacji, rozumianego jako „każdy dokument, z którego obywatel czerpie wiedzę o działalności administracji publicznej, a więc dokument związany z urzędową działalnością informacyjną" (s. 59), by następnie przedstawić własne rozumienie pojęcia aktu informacji w ujęciu wąskim. Jest nim mający podstawę prawną, określony prawem typ czynności konwencjonalnej podmiotów administracyjnych o charakterze z reguły niewładczym i niewiążącym w stosunku do jednostek administrowanych, nie kierowany do „pojedynczej jednostki”, lecz do wielu osób, związany z gromadzeniem, pozyskiwaniem, wykorzystywaniem i udzielaniem informacji oraz wywołujący skutki prawne w postaci aktualizacji obowiązków lub uprawnień innych podmiotów (s. 59-64). Przedstawiona definicja aktu informacji różni się od definicji informacji urzędowej jako formy działania administracji zaproponowanej przed laty przez niżej podpisanego. Przyjąłem wówczas, że „informacja przekazywana obywatelom przez administrację to oświadczenie wiedzy piastuna lub funkcjonariusza organu administracji państwowej albo innego podmiotu administrującego, dotyczące określonego stanu faktycznego, stanu prawnego czy wynikających z nich konsekwencji prawnych. Nie wywołuje ono bezpośrednio żadnych skutków prawnych, lecz może mieć wpływ na realizację pewnych uprawnień lub obowiązków odbiorcy informacji czy osób trzecich"’. Łatwo zauważyć, że w recenzowanym opracowaniu silny nacisk został położony na określenie zakresu odbiorców aktu informacji, ma to być bowiem społeczeństwo lub jego wydzielone grupy, ale nie jednostki legitymujące się interesem prawnym, więc automatycznie poza kręgiem oddziaływania aktu informacji pozostawiono czynności informacyjne organów skierowane do uczestników sformalizowanych postępowań administracyjnych. Wiąże się to z przyjętym we wstępie do monografii założeniem, że wyodrębnienie aktu informacji jest pochodną jego celu, tj. zapewnienia zainteresowanym udziału w sprawowaniu władzy publicznej. Bez ryzyka popełnienia błędu należy stwierdzić, że przedstawiona wyżej definicja aktu informacji stanowi w ostatnim czasie istotny wkład doktryny prawa administracyjnego odnośnie do pojmowania i klasyfikowania prawnych form działania administracji. Autorzy uzupełnili wywód o pokazanie,

3 Idem, Prawny obowiazek informowania obywateli przez organy administracji państwowej, „Państwo i Prawo” 1988, z. 1, s. 67. 
jak ujmowany jest akt informacji w orzecznictwie sądów administracyjnych, aby stwierdzić, że jest to pojęcie używane „niezwykle rzadko” i na dodatek niejednolicie rozumiane (s. 64-73).

Przedmiotem rozdziału IV jest akt informacji w ujęciu komparatystycznym. Autorzy posłużyli się w znacznym stopniu dorobkiem niemieckiej doktryny i judykatury, co nie powinno budzić zdziwienia, skoro pierwsze orzeczenia w sprawach informacji urzędowej pojawiły się tam już na początku ubiegłego wieku. Z licznych uwag i spostrzeżeń warto zaznaczyć: fakt wyodrębnienia „informacyjnego prawa administracyjnego" (s. 82-83); ograniczenie wolności działalności gospodarczej przez rozpowszechnienie informacji urzędowych wymaga podstawy zawartej w ustawie (s. 87), przy czym same działania informacyjne administracji wpisane są w otwartą funkcję państwa i z tej przyczyny nie wymagają ustawowego upoważnienia (s. 93-94); brak wypracowania jednolitego stanowiska doktryny prawa publicznego odnośnie do cech składających się na wyodrębnienie aktu informacji (s. 95). Należy zauważyć, że przyjmowany jest tam pogląd o konieczności badania przez naukę prawa dopuszczalności stosowania danej formy działania administracji (s. 92), podzielany przez rodzimą doktrynę, gdzie wskazuje się, iż formy stanowią rezultat swoistego współdziałania praktyki administracyjnej, orzecznictwa sądowego i nauki prawa ${ }^{4}$. Niemiecka doktryna prawa nieustająco dyskutuje problematykę wyprofilowania dwóch sprzecznych tendencji, tj. dążenia do ciągłego utrwalania stanu wolności rozpowszechniania informacji oraz pogłębiania skutecznych gwarancji ochrony interesów jednostek (s. 95). To właśnie z Niemiec pochodzi powiedzenie, że raz ujawniona informacja jest nieodwracalna jak kara śmierci ${ }^{5}$, które obecnie należy dyskutować w kontekście powszechnego dostępu do Internetu oraz ograniczonej możliwości wprowadzenia prewencyjnej ochrony sądowej uprawnień podmiotów dotkniętych nieprawdziwą informacją.

Ostatni rozdział monografii to przegląd zastosowania pojęcia aktu informacji w kilku działach szczególnej części prawa administracyjnego, a mianowicie planowania i zagospodarowania przestrzennego, ochrony środowiska, inżynierii genetycznej, nadzoru finansowego oraz prawa żywnościowego. Rozdział ten ma w dużej mierze charakter ilustracyjny, niemniej nie sposób pominąć poniższego ustalenia. Należy zgodzić się ze stwierdzeniem, że w przypadku organizmów genetycznie modyfikowanych można zaobserwować osiągnięcie przez prawo materialne „granic swoich możliwości regulacyjnych”. Ze względu na to, że szybki postęp biotechnologii pozostawia w tyle rozwiązania materialnoprawne, pozostaje

4 Zob. szerzej: idem, Zalecenie, ostrzeżenie i przyrzeczenie administracyjne w systemie form działania administracji publicznej, [w:] Administracja i prawo administracyjne u progu trzeciego tysiaclecia. Materiaty konferencji naukowej Katedr Prawa i Postepowania Administracyjnego, red. M. Stahl, J.P. Tarno, M. Górski, Łódź 2000, s. 465-466.

5 P. Krause, Rechtsformen des Verwaltungshandelns, Berlin 1974, s. 331. 
prawodawcy posłużenie się przepisami prawa formalnego i oparcie na procesowym modelu załatwiania spraw administracyjnych (s. 119). Uważam, że zamiast umiarkowanie szerokiego omawiania poszczególnych instytucji prawnych trafniejsze byłoby dokonanie porównania cech formy wynikających $\mathrm{z}$ referowanej ustawy z zaprojektowaną definicją aktu informacji. Lektura tego rozdziału skłania bowiem do zastanowienia się nad sposobami odróżniania podobnych do informacji form działania administracji publicznej. Funkcją informowania jest zwiększenie u odbiorcy informacji możliwości racjonalnego wyboru wariantu postępowania spośród dozwolonych przez prawo, natomiast jeżeli organ administracji preferuje określone z góry zachowanie, to mamy do czynienia z pokrewną informacji formą działania, a mianowicie z zaleceniem (preferencja w sposób warunkowy) lub radą (preferencja w sposób stanowczy). Z tego powodu rekomendacje Komisji Nadzoru Finansowego mogą być rozpatrywane nie tylko jako przykład soft law, lecz także jako zalecenia. Podobnie można podejść do ostrzeżeń publicznych regulowanych przepisami prawa żywnościowego ${ }^{6}$ i potraktować je jako zbliżoną do informacji formę ostrzeżenia, swego rodzaju rady, gdzie przez jego wydanie podmiot administrujący wskazuje odbiorcy pewne okoliczności niekorzystne w świetle dotychczasowego lub zamierzonego postępowania ${ }^{7}$. Powyższe uwagi dobrze wpisują się w końcowe stwierdzenie traktatu, że akt informacji ma niejednorodną strukturę i obejmuje niejednolitą grupę działań administracji publicznej (s. 153).

Według powszechnie uznawanej opinii prawne formy działania administracji to najbardziej skomplikowana część wykładu ogólnego prawa administracyjnego, wystarczy więc w tym miejscu ograniczyć się do stwierdzenia, że recenzowana monografia w pełni potwierdza powyższe zapatrywanie.

6 Ustawa z dnia 25 sierpnia 2006 r. o bezpieczeństwie żywności i żywienia (t.j. Dz.U. 2019, poz. 1252).

7 Na temat pokrewnych informacji form działania zob. W. Taras, Zalecenie, ostrzeżenie i przyrzeczenie administracyjne..., s. 468-471. 